\title{
Genetic variation among Phyllosticta strains isolated from citrus in Florida that are pathogenic or nonpathogenic to citrus
}

\author{
Maria Gabriela Mariduena Zavala ${ }^{1,2}$, Hong Ling Er ${ }^{1}$, Erica M. Goss ${ }^{1,3}$, Nan Yi Wang ${ }^{1,4}$, Megan Dewdney ${ }^{1,4}$ \\ \& Ariena H.C. van Bruggen ${ }^{1,3}$
}

${ }^{1}$ Department of Plant Pathology, University of Florida. 1453 Fifield Hall, Gainesville, FL32611-0680, USA; ${ }^{2}$ Centro de Investigaciones Biotecnológicas del Ecuador, Escuela Superior Politécnica del Litoral, Guayaquil- Ecuador; ${ }^{3}$ Emerging Pathogen Institute, University of Florida.P.O. Box 100009, 2055 Mowry Road Gainesville, FL 32610, USA; ${ }^{4}$ Citrus Research and Education Center, University of Florida, 2685 SR29N, Lake Alfred, FL34142-9515, USA

Author for correspondence: Ariena H.C.van Bruggen, e-mail: ahcvanbruggen@ufl.edu

\begin{abstract}
Citrus black spot is an emerging disease in Florida since 2010. The causal agent is Phyllosticta citricarpa (teleomorph Guignardia citricarpa), but non-pathogenic P. capitalensis (teleomorph often referred to as G. mangiferae) is often isolated from black spot lesions. Florida isolates of P. citricarpa and P. capitalensis from citrus have not been characterized in detail. In this study, Phyllosticta species isolated from Florida citrus were compared with worldwide isolates using multi-locus sequencing of four conserved loci (rDNA ITS, TEF1, ACT, and GPDH genes). Moreover, the diversity within the two Phyllosticta species was compared based on the same four loci. DNA sequences of $P$. citricarpa and $P$. capitalensis were clearly distinct, coinciding with other $P$. citricarpa and $P$. capitalensis sequences from different continents. The species showed different population structures in Florida. $P$. citricarpa isolates did not exhibit genetic variation and were similar to strains from other continents. In contrast, Florida $P$. capitalensis isolates were distributed over five sequence groups. This study did not point to the potential origin of $P$. citricarpa and $P$. capitalensis in Florida. More variable genetic markers and isolates from various continents would be required to track the possible movement of these Phyllosticta species.

Key words: Citrus sinensis, Guignardia citricarpa, Guignardia mangiferae, Phyllosticta capitalensis, Phyllosticta citricarpa, phylogenetic study.
\end{abstract}

\section{INTRODUCTION}

Citrus black spot (CBS) is one of several emerging citrus diseases in Florida (Chiyaka et al., 12; Dewdney et al., 2012; Shen et al., 2013). The disease was recently found for the first time in a few orange groves in south Florida in 2010 (Schubert et al., 2012). Since then, CBS has spread through a large part of three counties (about half of $9,000 \mathrm{~km}^{2}$ affected) in south Florida, but not yet to mid and north Florida. The disease has been common in Australia since the nineteenth century inflicting heavy losses for many years, particularly in coastal regions with relatively humid climates (Kotzé, 1981). Around the 1920s, it was found in South Africa, first along the coastal region, then spreading inland to the main citrus production areas, causing major damage (Kotzé, 1981). CBS is now present in South East Asia, many countries in Africa (Brentu et al., 2012), several countries in South America (Dewdney et al., 2012; Paul et al., 2005), and North America (Florida only thus far; Er et al., 2013b). The disease is not yet present in Europe (Paul et al., 2005). Phyllosticta citricarpa McAlpine van der Aa (teleomorph Guignardia citricarpa Kiely)is an A1 quarantine pest for Europe, and import of citrus from regions positive for the disease is banned (Paul et al., 2005).

The disease is associated with severe fruit spotting and fruit drop (Dewdney et al., 2012). This is especially problematic for the fresh fruit industry, because infected fruit are unmarketable as fresh fruit. To prevent further spread from south Florida, quarantine zones have been established around affected areas, and strict regulations have been instituted for the transport of infected fruit and citrus waste. Further spread in Florida and the US would cause severe losses nationally and jeopardize the export of fresh fruit to overseas markets.

CBS is caused by $P$. citricarpa but the pathogen is often accompanied by nonpathogenic strains of Phyllosticta, mostly identified as P. capitalensis Hennings (teleomorph often referred to as Guignardia mangiferae Roy) (Baldassari et al., 2008). However, strains that have been described as $G$. mangiferae do not always have $P$. capitalensis as anamorph (Glienke et al., 2011). P. capitalensis has been found on CBS affected citrus trees as well as healthy and asymptomatic trees, and has a wider host range than $P$. citricarpa extending beyond the Rutaceae, commonly as an endophyte (Baayen et al., 2002; Bezerraet al., 2012; Everett 
\& Rees-George, 2006; Glienke et al., 2011; Johnston, 1998; Okane et al., 2001; Rakotoniriana et al., 2008; Rodrigues \& Samuels, 1999; Rodrigues et al., 2004; Yuan et al., 2009). Guignardia mangiferae sensu stricto (not necessarily $P$. capitalensis) is a pathogen of mango (Mangifera indica $\mathrm{L}$ ), but is nonpathogenic to other species (Baldassari et al., 2008; Glienke et al., 2011). Conversely, although P. citricarpa can be isolated from citrus fruit with CBS lesions, it has also been found in asymptomatic citrus tissues (Baldassari et al., 2008), but not in plant species outside of the Rutaceae. Phyllosticta capitalensis was sometimes misidentified as P. citricarpa before Baayen et al. (2002) classified it as $P$. capitalensis (Everett \&Rees-George, 2006; Glienke-Blanco et al., 2002).

Phyllostica citricarpa and P. capitalensis can be distinguished morphologically and physiologically based on colony type on oatmeal agar (yellow halo present around $P$. citricarpa but absent around colonies of $P$. capitalensis), growth rate (generally faster for $P$. capitalensis), conidia size (larger for $P$. capitalensis), and hydrolytic enzyme production (higher production by $P$. citricarpa) (Baayen et al., 2002; Glienke et al., 2011; Romão et al., 2011). In addition, the two groups were clearly distinct based on sequences of the rDNA internal transcribed spacer (ITS) region, while the ITS sequences of the isolates used were quite uniform within each group, identified as either $P$. citricarpa or $P$. capitalensis (Romão et al., 2011). Uniformity in the ITS region was also found for many isolates of $P$. capitalensis from Japan (Okane et al., 2003) or P. capitalensis from Brazil (Rodrigues et al., 2004). Others found some variation in the ITS region of isolates of $P$. capitalensis (Wickert et al., 2012b) but high similarity in ITS sequences of $P$. citricarpa isolates from Brazil (Wickert et al., 2012a).When multi-locus analyses were carried out on a large number of Phyllosticta species more variation was detected (Glienke et al., 2011; Wang et al., 2012; Wulandariet al., 2009). Using three DNA regions, the rDNA internal transcribed spacer (ITS) region, the partial translation elongation factor 1-alpha (TEF1), and the actin gene (ACT), three Phyllosticta clades associated with citrus in Thailand were distinguished, namely $P$. capitalensis, $P$. citricarpa and Phyllosticta citriasiana Wulandari, Crous \& Gruyter (Wulandari et al., 2009). Using the same three primer sets, Wang et al. (2012) distinguished four clades, and described one new species associated with citrus in China, namely Phyllosticta citrichinaensis X.H. Wang, K.D. Hyde \& H.Y. Li. They were also able to distinguish two groups of $P$. citricarpa, one on mandarin and one on orange and lemon. When the number of sequenced DNA regions was increased to four, including the glyceraldehyde-3-phosphate dehydrogenase (GPDH) gene in addition to the three other regions used by Wulandari et al. (2009) and Wang et al. (2012), nine clades were distinguished (Glienke et al., 2011). Five of these contained isolates associated with citrus: P. citricarpa, P. citriasiana, Phyllosticta citribraziliensis C. Glienke \& Crous, Phyllosticta brazilianiae D. Stringari,
C. Glienke \& Crous, and P. capitalensis. P. citricarpa is the pathogen causing black spot on many citrus species. P. citriasiana is a pathogen causing tan spot on pummelo (Citrus maxima Merr.), P. citrichinaensis is a very weak pathogen on various citrus species, $P$. citribraziliensis and $P$. brazilianae are nonpathogenic endophytes in citrus and mango, respectively, and $P$. capitalensis is the broad host range endophyte commonly referred to as $G$. mangiferae (Glienke et al., 2011). In addition to phylogenetic analyses based on DNA sequences, grouping of pathogenic and nonpathogenic Phyllosticta isolates from citrus was obtained using AFLP (Baldassari et al., 2008) and RAPD markers (Stringari et al., 2009). The variation in these markers was greater among nonpathogenic isolates than among pathogenic isolates (Baayen et al., 2002; Baldassari et al., 2008; Glienke et al., 2011; Stringari et al., 2009).

In Florida, a limited number of Phyllosticta isolates has been obtained from citrus thus far (Er et al., 2013a). Based on ITS sequence analysis, $P$. citricarpa was distinguished from $P$. capitalensis, and the variation in $P$. capitalensis seemed to be greater than that of $P$. citricarpa. This was also true for the temperature response curves, the growth rates on PDA and sensitivity to copper (Er et al., 2013a). A greater diversity of ITS regions of $P$. capitalensis compared to $P$. citricarpa had been observed previously (Glienke-Blanco et al., 2011; Wang et al., 2012; Wikee et al., 2011). However, none of the taxonomic studies cited above contained isolates from Florida, and it is important to know if the Florida isolates form a subset of those in Brazil or if Florida isolates have some unique sequences, especially among P. citricarpa strains. To make this distinction multi-locus sequencing is needed. The objectives of this study were therefore: 1) to compare Florida isolates of $P$. citricarpa and $P$. capitalensis from citrus with those of citrus isolates worldwide using multi-locus sequencing, and 2) to investigate if isolates of $P$. capitalensis are more diverse than those of $P$. citricarpa based on the same set of gene sequences.

\section{MATERIAL AND METHODS}

\section{Phyllosticta isolates used}

Leaves and fruits of Valencia sweet orange, Citrus sinensis (L.) Osbeck, with or without symptoms of CBS were collected in Immokalee (southwest Florida). Leaves and fruits were cut into small pieces, surface sterilized in a sodium hypochlorite solution (10\%) for 20 seconds, followed by $70 \%$ ethanol for 30 seconds, and rinsed three times in sterilized water. The fragments were then placed on potato dextrose agar (PDA) and incubated at $25^{\circ} \mathrm{C}$ until colonies were found that were characteristic for Phyllosticta species. Subcultures were transferred to oatmeal agar (OA) and colonies were checked for a yellow halo to distinguish $P$. citricarpa from $P$. capitalensis (Baayen et al., 2002). Morphology and size of conidia were checked microscopically (Wikee et al., 2011). To confirm the identity 
of the isolates as P. citricarpa or P. capitalensis the rDNA ITS region was amplified and sequenced as previously reported (Er et al., 2013a). In addition to the isolates from citrus tissues in Florida, 5 Phyllosticta strains were purchased from the Centraal Bureau voor Schimmelcultures in the Netherlands. All cultures were stored on PDA slants at $4^{\circ} \mathrm{C}$. Details about isolates used in this study are provided in Table 1.

\section{DNA extraction}

Cultures were transferred to fresh PDA, and DNA was extracted from 1-2week old cultures with a DNeasy Plant Mini Kit (Qiagen, USA) according to the manufacturer's protocol.

\section{DNA amplification}

The rDNA internal transcribed spacer region (ITS) was amplified using primers ITS1-F and ITS4 (White et al., 1990). The translation elongation factor $1-\alpha$ gene (TEF1) and actin gene (ACT) of $P$. capitalensis and P. citricarpa were amplified using primers EF1-728F and EF1-986R, and ACT-512F and ACT-783R, respectively (Carbone \& Kohn, 1999). The glyceraldehyde-3-phosphate dehydrogenase (GPDH) gene was amplified using primers GDF1 (Guerber et al., 2003) and Gpd2-LM (Myllys et al., 2002) or GDR1 (Guerber et al., 2003) for $P$. capitalensis isolates, and GDF1 and GPDHR2 (Glienke, et al., 2011) for the P. citricarpa isolates (Table 2).

Amplification reactions were performed with $0.5 \mu \mathrm{l}$ of DNA, $0.4 \mu \mathrm{l}$ of dNTP (final concentration $=0.20 \mathrm{mM}$ ), $0.4 \mu \mathrm{l}$ each of the forward and reverse primers $(0.2 \mu \mathrm{M}$ each of the primer), $14.9 \mu \mathrm{l}$ of ultrapure water, $2 \mu \mathrm{l}$ of $10 \mathrm{X}$ Amplitaq ${ }^{\circledR}$ Gold Buffer (Applied Biosystems, USA) (1X), $2 \mu \mathrm{l}$ of $\mathrm{MgCl}_{2}(2.5 \mathrm{mM})$ and $0.2 \mu$ ofAmplitaq ${ }^{\circledR}$ Gold Taq polymerase $(1 \mathrm{U} / \mu \mathrm{l})$ in a total reaction volume of $20 \mu \mathrm{l}$. The PCR program depended on the primer set used. For the ITS region, initial heating was at $94^{\circ} \mathrm{C}$ for $2 \mathrm{~min}$, followed by 39 cycles of $94^{\circ} \mathrm{C}$ for $30 \mathrm{~s}, 55^{\circ} \mathrm{C}$ for $30 \mathrm{~s}$ and $72^{\circ} \mathrm{C}$ for $1 \mathrm{~min}$, and then a final elongation at $72^{\circ} \mathrm{C}$ for $10 \mathrm{~min}$ (Er et al., 2013a). For the TEF1 and ACT genes, initial denaturalization was at $94^{\circ} \mathrm{C}$ for $5 \mathrm{~min}$, followed by 30 cycles of $94^{\circ} \mathrm{C}$ for $30 \mathrm{~s}$, $52^{\circ} \mathrm{C}$ for $30 \mathrm{~s}, 72^{\circ} \mathrm{C}$ for $30 \mathrm{~s}$, and the final elongation step was at $72^{\circ} \mathrm{C}$ for $7 \mathrm{~min}$. For the GPDH genes the initial denaturalization took place at $95^{\circ} \mathrm{C}$ for $5 \mathrm{~min}$, followed by 35 cycles at $95^{\circ} \mathrm{C}$ for $30 \mathrm{~s}, 50^{\circ} \mathrm{C}$ for $30 \mathrm{~s}, 72^{\circ} \mathrm{C}$ for $90 \mathrm{~s}$, and the final elongation step was at $72^{\circ} \mathrm{C}$ for $7 \mathrm{~min}$.

The bands generated were revealed in a $1.0 \%$ agarose gel in solution TAE $1 \mathrm{X}$ (Tris base, boric acid and EDTA $0,5 \mathrm{M}, \mathrm{pH} 8,0)$ using $5 \mu \mathrm{l}$ of PCR product with $1 \mu \mathrm{l}$ of loading dye (Promega, USA) at 100 volts during $20 \mathrm{~min}$ with a100bp Low Scale DNA Ladder (Fisher Scientific, USA).

\section{DNA sequencing}

PCR products were purified using a Wizard ${ }^{\circledR}$ SV Gel and PCR Clean-Up System (Promega Corporation,
Wisconsin, USA) according to the manufacturer's protocol. The purified products were sequenced using ABI big dye chemistry and ABI 3730xl and 3130xl genetic analyzers (Applied Biosystems, USA) in the Interdisciplinary Center for Biotechnology Research (ICBR) at the University of Florida.

\section{Alignment of sequences}

The DNA sequences were visualized and manually edited in the chromatogram viewer Finch TV version 1.4.0 (Geospiza Inc.). Analysis and comparison with sequences in Genbank was performed using BLAST (http://www. ncbi.nlm.nih.gov/BLAST/). The ITS, ACT and TEF1 gene sequences of reference Phyllosticta and Guignardia species were obtained from the CBS fungus database (http://www. cbs.knaw.nl/databases/) and all sequences used in Glienke et al. (2011) and Wang et al. (2012) were downloaded from NCBI GenBank. The ITS, ACT, TEF 1 and GPDH sequences from all isolates were aligned separately with MUSCLE in the program MEGA version 5 (Tamura et al., 2011) and checked by eye.

\section{Phylogenetic trees}

Maximum likelihood was used to infer phylogenetic trees using NNI topology search under the GTR substitution model with estimated proportion of invariable sites and gamma distribution parameter. The program PhyML (Guindon \& Gascuel2003) was used as implemented in Geneious 6.16 (Biomatters Ltd.). Phylogenetic trees were inferred for each locus separately and concatenated sequences using all of the Phyllosticta sequences from Glienke et al. (2011). Upon finding concordance with the Phyllosticta tree in Glienke et al. (2001), phylogenetic analysis was conducted separately for $P$. citricarpa and $P$. capitalensis. For $P$. citricarpa, all four genes were concatenated and $P$. citriasiana was used as the out-species. For $P$. capitalensis, two phylogenetic trees were constructed, one for concatenated ITS, TEF1, and ACT sequences and another for the GPDH gene. The Wang et al. (2012) sequences for $P$. capitalensis were included in the 3-locus tree. The divergent strain IMI260.576 was used to root the P. capitalensis trees. Support was assessed by 500 bootstrap replicates. Trees were visualized in FigTree v1.4.0 (A. Rambaut, http://tree.bio.ed.ac.uk/).

\section{Phyllosticta capitalensis population structure}

Genetic variation in P. capitalensis was examined by region using the concatenated sequences of the four genes using Florida isolates and isolates sequenced for the same four loci (Glienke et al., 2011). The software DnaSP v5.10.01 (Rozas et al., 2003) was used to quantify sequence variation. Variation was quantified for each region represented by two or more isolates, with Florida and Hawaii considered separately. Population structure was further examined by calculating pairwise $\mathrm{F}_{\mathrm{ST}}$ and conducting an analysis of molecular variance (AMOVA) in Arlequin 3.5 (Excoffier \& Schneider, 2005) using concatenated sequences and Tamura 
M.G.M. Zavala et al.

TABLE 1 - Information on strains of Phyllosticta citricarpa and P. capitalensis used in this study.

\begin{tabular}{|c|c|c|c|c|c|}
\hline $\begin{array}{l}\text { Strain } \\
\text { number }\end{array}$ & Phyllosticta species & $\begin{array}{l}\text { Date of } \\
\text { isolation }\end{array}$ & Host tree & Location & Accession number \\
\hline Pcit1 & P. citricarpa & May2010 & $\begin{array}{l}\text { Valencia } \\
\text { orange }\end{array}$ & Immokalee, FL & $\begin{array}{l}\text { KC311457 (ITS), } \\
\text { KF147996 (TEF), KF147990 } \\
\text { (ACT), KF148015(GPDH) }\end{array}$ \\
\hline Pcit2 & P. citricarpa & May2010 & $\begin{array}{l}\text { Valencia } \\
\text { orange }\end{array}$ & Immokalee, FL & $\begin{array}{l}\text { KC311458 (ITS), } \\
\text { KF147997 (TEF), KF147991 } \\
\text { (ACT), KF148016 (GPDH) }\end{array}$ \\
\hline Pcit3 & P. citricarpa & Mar2011 & $\begin{array}{l}\text { Valencia } \\
\text { orange }\end{array}$ & Immokalee, FL & $\begin{array}{l}\text { KC311459 (ITS), } \\
\text { KF147998 (TEF), KF147992 } \\
\text { (ACT), KF148017 (GPDH) }\end{array}$ \\
\hline Pcit15 & P. citricarpa & Dec2011 & $\begin{array}{l}\text { Valencia } \\
\text { orange }\end{array}$ & Immokalee, FL & $\begin{array}{l}\text { KC311462 (ITS), } \\
\text { KF147999 (TEF), } \\
\text { KF147993(ACT), KF148018 } \\
\text { (GPDH) }\end{array}$ \\
\hline Pcit24 & P. citricarpa & Feb2012 & $\begin{array}{l}\text { Valencia } \\
\text { orange }\end{array}$ & Immokalee, FL & $\begin{array}{l}\text { KC311465 (ITS), } \\
\text { KF148000 (TEF), KF147994 } \\
\text { (ACT), KF148019 (GPDH) }\end{array}$ \\
\hline DPI 35197 & P. citricarpa & Mar2010 & $\begin{array}{l}\text { Valencia } \\
\text { orange }\end{array}$ & Immokalee, FL & $\begin{array}{l}\text { KC311466 (ITS), } \\
\text { KF148001 (TEF), KF147995 } \\
\text { (ACT), KF148020 (GPDH) }\end{array}$ \\
\hline CBS102373 & P. citricarpa & 1999 & Fruit & Brazil & $\begin{array}{l}\text { FJ538312 (ITS), } \\
\text { FJ538370 (TEF), } \\
\text { FJ538428 (ACT), } \\
\text { JF343678 (GPDH) }\end{array}$ \\
\hline CBS122482 & P. citricarpa & 2008 & Fruit & Zimbabwe & $\begin{array}{l}\text { FJ538317 (ITS), } \\
\text { FJ538375 (TEF), } \\
\text { FJ538433 (ACT), } \\
\text { JF343677 (GPDH) }\end{array}$ \\
\hline Pcap2 & P. capitalensis & May2010 & $\begin{array}{l}\text { Valencia } \\
\text { young twig }\end{array}$ & Immokalee, FL & $\begin{array}{l}\text { KC311448 (ITS), } \\
\text { KF148002 (TEF), KF147982 } \\
\text { (ACT), KF148007 (GPDH) }\end{array}$ \\
\hline Pcap4 & P. capitalensis & May2010 & $\begin{array}{l}\text { Valencia } \\
\text { young twig }\end{array}$ & Immokalee, FL & $\begin{array}{l}\text { KC311450 (ITS), } \\
\text { KF147983 (ACT), KF148008 } \\
\text { (GPDH) }\end{array}$ \\
\hline Pcap5 & P. capitalensis & May2010 & $\begin{array}{l}\text { Valencia } \\
\text { orange }\end{array}$ & Immokalee, FL & $\begin{array}{l}\text { KC311451 (ITS), } \\
\text { KF148003 (TEF), KF147984 } \\
\text { (ACT), KF148009 (GPDH) }\end{array}$ \\
\hline Pcap6 & P. capitalens is & May2010 & Grapefruit & Immokalee, FL & $\begin{array}{l}\text { KC311452 (ITS), } \\
\text { KF148004 (TEF), KF147985 } \\
\text { (ACT), KF148010 (GPDH) }\end{array}$ \\
\hline Pcap31-1S & P. capitalensis & Mar2011 & $\begin{array}{l}\text { Valencia } \\
\text { orange }\end{array}$ & Immokalee, FL & $\begin{array}{l}\text { KC878296 (ITS), KF148005 } \\
\text { (TEF), KF147986 (ACT), } \\
\text { KF148011 (GPDH) }\end{array}$ \\
\hline Pcap32-1S & P. capitalensis & Mar2011 & $\begin{array}{l}\text { Valencia } \\
\text { orange }\end{array}$ & Immokalee, FL & $\begin{array}{l}\text { KC } 878297 \text { (ITS), KF147987( } \\
\text { ACT), KF148012 (GPDH) }\end{array}$ \\
\hline Pcap33-2S & P. capitalensis & Mar2011 & $\begin{array}{l}\text { Valencia } \\
\text { orange }\end{array}$ & Immokalee, FL & $\begin{array}{l}\text { KC878298 (ITS), KF148006 } \\
\text { (TEF), KF147988 (ACT), } \\
\text { KF148013 (GPDH) }\end{array}$ \\
\hline Pcap33-3S & P. capitalensis & Mar2011 & $\begin{array}{l}\text { Valen cia } \\
\text { orange }\end{array}$ & Immokalee, FL & $\begin{array}{l}\text { KC878299 (ITS), KF147989 } \\
\text { (ACT), KF148014 (GPDH) }\end{array}$ \\
\hline CBS100176 & P. capitalensis & 1997 & Leaf & Brazil & $\begin{array}{l}\text { FJ538321 (ITS), } \\
\text { FJ538379 (TEF), } \\
\text { FJ538437 (ACT), } \\
\text { JF343704 (GPDH) }\end{array}$ \\
\hline CBS123374 & P. capitalensis & 2007 & $\mathrm{NA}^{1}$ & Thailand & $\begin{array}{l}\text { FJ538332 (ITS), } \\
\text { FJ538390 (TEF), } \\
\text { FJ538448 (ACT), } \\
\text { JF343702 (GPDH) }\end{array}$ \\
\hline CBS123370 & $\begin{array}{l}\text { Phyllosticta } \\
\text { citriasiana }\end{array}$ & 2007 & NA & Vietnam & $\begin{array}{l}\text { FJ538355 (ITS), } \\
\text { FJ538413 (TEF), } \\
\text { FJ538471 (ACT), } \\
\text { JF343689 (GPDH) }\end{array}$ \\
\hline
\end{tabular}

${ }^{1}$ Not available 
TABLE 2 - Primer pairs used in this study.

\begin{tabular}{|c|c|c|}
\hline Primer name & Sequence & Reference \\
\hline ITS4R & 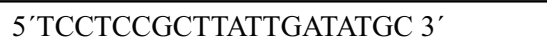 & White et al. (1990) cited by Su\& Cai (2012) \\
\hline ITS1F & 5'CTTGGTCATTTAGAGGAAGTAA 3' & White et al. (1990) cited by Su \& Cai (2012) \\
\hline $\mathrm{EF} 1-728 \mathrm{~F}$ & 5'CATCGAGAAGTTCGAGAAGG 3' & $\begin{array}{l}\text { Carbone \& Kohn (1999) cited by Su \& Cai } \\
\text { (2012) }\end{array}$ \\
\hline EF-986R & 5'TACTTGAAGGAACCCTTACC3' & $\begin{array}{l}\text { Carbone \& Kohn (1999) cited by Su\& Cai } \\
\text { (2012) }\end{array}$ \\
\hline ACT-512F & 5'ATGTGCAAGGCCGGTTTCGC3' & $\begin{array}{l}\text { Carbone \& Kohn (1999) cited by Su \& Cai } \\
\text { (2012) }\end{array}$ \\
\hline ACT-783R & 5'TACGAGTCCTTCTGGCCCAT3' & $\begin{array}{l}\text { Carbone \& Kohn (1999) cited by Su \& Cai } \\
\text { (2012) }\end{array}$ \\
\hline GDF1 & 5'GCCGTCAACGACCCCTTCATTGA3' & $\begin{array}{l}\text { Guerber et al. (2003) cited by Su \& Cai } \\
\text { (2012) }\end{array}$ \\
\hline Gpd2-LM & 5'CCCACTCGTTGTCGTACCA3' & $\begin{array}{l}\text { Myllys et al. (2002) cited by Su \& Cai } \\
\text { (2012) }\end{array}$ \\
\hline GDR1 & 5'GGGTGGAGTCGTACTTGAGCATGT3' & $\begin{array}{l}\text { Guerber et al. (2003) cited by Su \& Cai } \\
\text { (2012) }\end{array}$ \\
\hline GPDHR2 & 5'CTCRGMRGCRGCCTTGATGG 3' & Glienke et al.ı (2011) \\
\hline
\end{tabular}

and Nei distance. Both used 10,000 permutations to assess significance.

\section{RESULTS}

Based on our multilocus genetic analysis, DNA sequences of $P$. citricarpa and $P$. capitalensis isolates from Florida citrus trees were identical or similar, respectively, to sequences of other $P$. citricarpa and $P$. capitalensis isolates worldwide.

The $P$. citricarpa isolates from Florida were identical across the four genes sequenced (Figure 1). They were also identical to $P$. citricarpa isolated from Brazil, Australia, and Africa, and corresponded to P. citricarpa subclade-I in Wang et al. (2012).

Phyllosticta capitalensis exhibited sequence variation within the Florida sample represented by 5 different sequence haplotypes (Table 3). All P. capitalensis isolates examined, for the combined sequences, produced 26 sequence haplotypes, plus the diverged $G$. mangiferae isolate from India, IMI260.576. The GPDH gene was the most variable with 10 segregating sites and 8 haplotypes, characterized by two major haplotypes separated by four nucleotide differences. The phylogenetic tree for GPDH was not congruent with those for the other three loci, potentially indicating recombination in this species (Figure $2 \mathrm{a}$ and $\mathrm{b}$ ). Isolates from Florida shared identical haplotypes at all four loci with isolates from Brazil, Thailand, South Africa, and New Zealand. Two Florida isolates had unique GPDH haplotypes, Pcap5 from this study and isolate 16 sequenced by Glienke et al. (2011). Sequence variation in $P$. capitalensis was observed for each location represented by at least two isolates (Table 3 ).

We tested for population structure in $P$. capitalensis between Florida, Brazil, and Thailand because of the slightly larger sample sizes for these locations at 9, 37, and
7 , respectively. The within population variation component accounted for most of the variation in the combined sample, however there was a significant genetic variation among these populations as well (Tables 3 and 4). $\mathrm{F}_{\mathrm{ST}}$, a pairwise measure of variation between populations, was significant between Brazil and Thailand for $P<0.05$.

\section{DISCUSSION}

Based on the multilocus genetic analysis carried out in this research, $P$. citricarpa and $P$. capitalensis isolates from Florida citrus trees fit in the known phylogenetic structure of Phyllosticta species published recently (Glienke et al., 2011). Their sequences were identical or similar to sequences of other $P$. citricarpa and $P$. capitalensis isolates, respectively.

Phyllosticta citricarpa and $P$. capitalensis on citrus in Florida have distinctly different population structures. $P$. citricarpa does not exhibit genetic variation in Florida and exhibits limited variation worldwide, based on three or four conserved genes. The lack of sequence variation supports the hypothesis that this pathogen has only recently been introduced to citrus-producing regions in the United States, Brazil, Africa, and Australia (Glienke et al., 2011; Er et al, 2013a; Schubert et al., 2012). In Asia (the center of origin of Citrus species), the diversity of $P$. citricarpa was greater when more Citrus species were sampled (Wang et al., 2012). Two groups of $P$. citricarpa originating from different citrus hosts were found in China (Wang et al., 2012). More variable genetic markers and many isolates from various continents will be required to track the global emergence of this pathogen. Thus, the origin of $P$. citricarpa in Florida is uncertain at this time and could possibly have been in Latin America or Asia.

In contrast to $P$. citricarpa, the non-pathogenic $P$. capitalensis from Florida produced five different sequence 
M.G.M. Zavala et al.

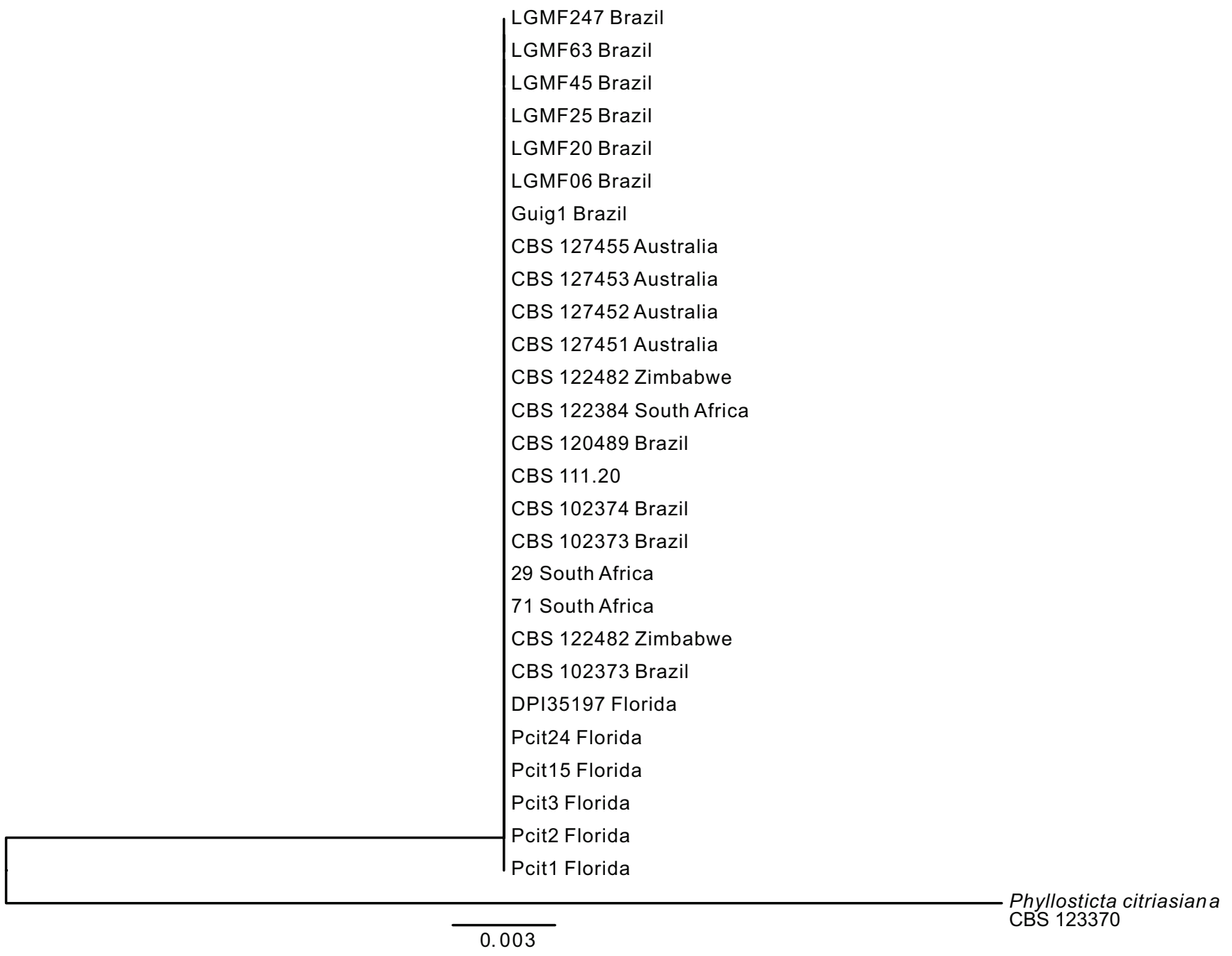

FIGURE 1- Maximum likelihood phylogenetic tree for Phyllosticta citricarpa based on the concatenated sequences of ITS, TEF1, ACT, and GPDH. All of the P. citricarpa isolates have identical sequences. The tree was rooted with corresponding sequence from $P$. citriasiana. Scale bar indicates branch lengths in substitutions per site.

TABLE 3 - Sequence variation by location.

\begin{tabular}{lccccc}
\hline \hline Location & Number of isolates & Segregating sites & $\begin{array}{c}\text { Number of } \\
\text { haplotypes }\end{array}$ & $\boldsymbol{\theta}_{\mathbf{w}}{ }^{1}$ & $\boldsymbol{\pi}^{2}$ \\
\hline Florida & 9 & 8 & 5 & 2.943 & 0.00339 \\
Brazil & 37 & 17 & 14 & 4.072 & 0.00252 \\
Thailand & 7 & 11 & 6 & 4.490 & 0.00409 \\
Hawaii & 2 & 6 & 2 & 6.00 & 0.00535 \\
South Africa & 2 & 3 & 2 & 3.00 & 0.00267 \\
New Zealand & 2 & 6 & 2 & 6.00 & 0.00535 \\
\hline
\end{tabular}

${ }^{1}$ Watterson's theta per gene, a measure of effective population size.

${ }^{2}$ Average pairwise nucleotide diversity.

groups. The grouping was somewhat different based on the concatenated ITS, TEF1 and ACT loci compared to that based on the GPDH gene (Figure 2), indicating possible recombination in this species. Indeed, ascospores of $P$. capitalensis can be readily found in citrus leaf litter (Dewdney, unpublished). Baldassari et al. (2008) and Wang et al. (2012) also detected greater diversity in P. capitalensis than in P. citricarpa using AFLP and the sequences of three loci, respectively. The haplotypes of $P$. capitalensis detected in Florida were previously observed in Brazil as well as Thailand, New Zealand, and South Africa. P. capitalensis in Florida shares similarity with Brazil and the equally diverse population in Thailand, but is distinct from these populations and does not appear to have their same level of diversity. 
A
B

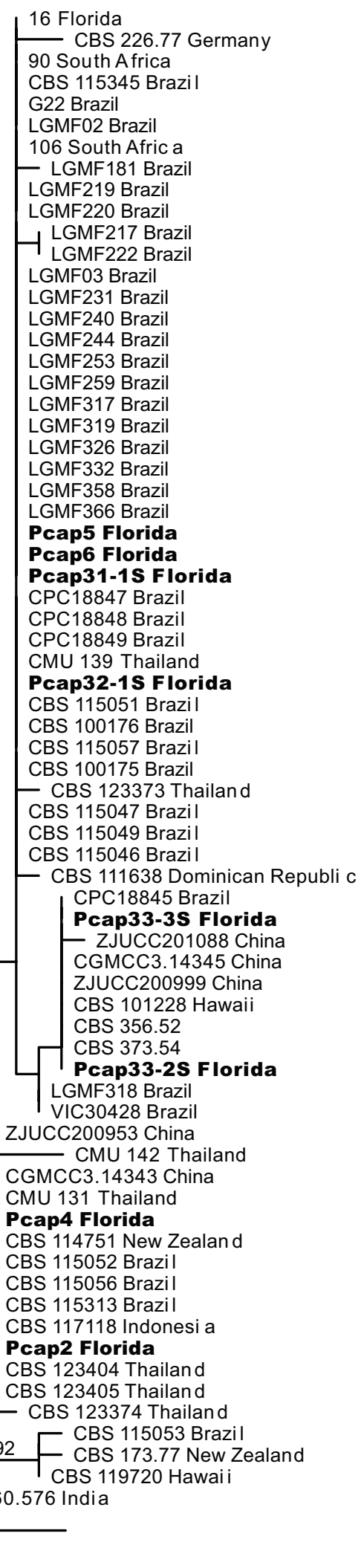

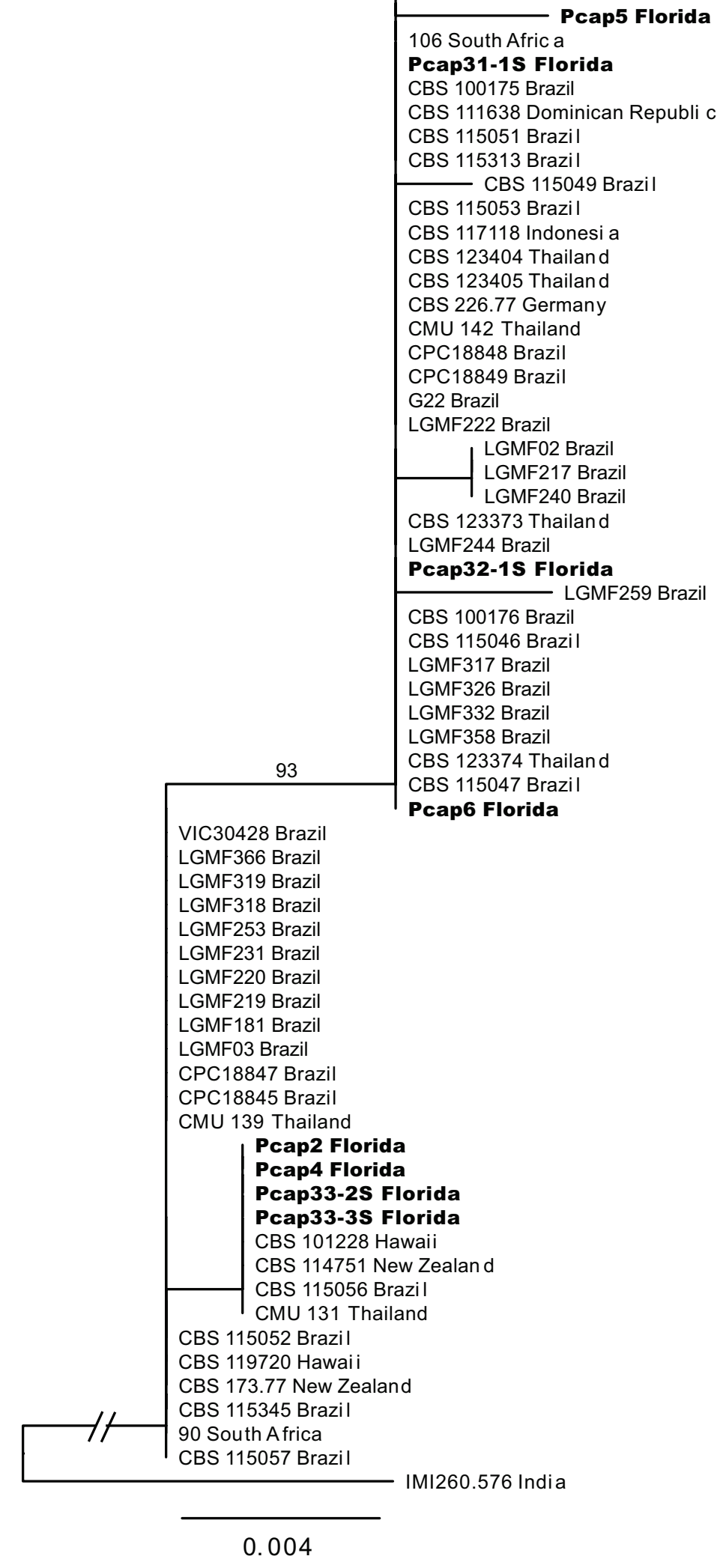

FIGURE 2 - Maximum likelihood phylogenetic trees for Phyllosticta capitalensis rooted with Guignardia mangiferae strain IMI 260576. Isolates sequenced in this study are bolded. A. Phylogeny based on concatenated ITS, TEF1, and ACT loci. B. Phylogenetic relationships based on the GPDH gene sequence. Branch labels show percent support from 500 bootstrap replicates when it exceeded 80\%. Most clades were not well supported. The scale bars reference branch lengths in substitutions per site. 
M.G.M. Zavala et al.

TABLE 4 - Analysis of molecular variance for Florida, Brazil, Thailand samples.

\begin{tabular}{lcccc}
\hline \hline Source of variation & Degrees of freedom & Sum of Squares & Variance components & \% Variation \\
\hline Among locations & 2 & 6.73 & 0.15 & $8.5^{*}$ \\
Within locations & 50 & 78.52 & 1.57 & 91.5 \\
\hline$* P=0.045$ & & &
\end{tabular}

$* P=0.045$

Thus, $P$. capitalensis could have been introduced in Florida, but possibly before the introduction of $P$. citricarpa or more frequently than this pathogen. Again, more variable genetic markers and more isolates from various continents would be required to reconstruct the movement of $P$. capitalensis.

The non-pathogenic Phyllosticta strains, including P. capitalensis, are typical endophytes (Baayen et al., 2002) that can have various beneficial properties like fending off insect pests and pathogens or producing medicinal metabolites and hydrolytic enzymes (Arnold et al., 2003; Kelemu et al., 2001; Mejía et al., 2008; Rakotoniriana et al., 2008; Rodrigues et al., 2000). Phyllosticta citricarpa might be suppressed by $P$. capitalensis in citrus tissues, because some $P$. capitalensis isolates outgrew $P$. citricarpa when compared in competition tests on agar plates (Baayen et al., 2002; Er et al., 2013a). However, the composition of endophytic mycobiota such as Phyllosticta spp. is strongly dependent on crop management and likely soil quality (Johnston, 1998) or other environmental conditions. Previously, we hypothesized that $P$. citricarpa might have been present before it was detected in Florida but that black spot disease caused by this fungus did not manifest itself due to competition by endophytic $P$. capitalensis (Er et al., 2013a). Increased copper applications to control citrus canker in recent years could have shifted the balance towards increased growth and infection by $P$. citricarpa thereby facilitating the emergence of CBS in Florida. However, this hypothesis was rejected because two isolates of $P$. capitalensis (Pcap2 and Pcap5 belonging to different DNA sequence clades) proved more resistant or equally sensitive to copper as compared to P. citricarpa (Er et al., 2013a). Phyllosticta capitalensis isolates were also more variable in their temperature response than $P$. citricarpa isolates, the former having a wider temperature range for growth in culture than the latter (Er et al., 2013a). This suggests broader adaptability and potentially greater competitiveness of $P$. capitalensis as compared to $P$. citricarpa.

Differences in temperature and copper sensitivity as well as relative growth rates among isolates of $P$. capitalensis seem to reflect differences in DNA sequences as determined in this paper using four primer pairs. Using ITS primers only, two subgroups of $P$. capitalensis could be distinguished that coincided with broad groupings according to growth rates and temperature or copper sensitivity ( $\mathrm{Er}$ et al., 2013a). Additional isolates of $P$. capitalensis from different continents will need to be tested for various physiological traits allow for group distinction in $P$. capitalensis based on phenotypic as well as genotypic variation. This study already contributed significantly towards our understanding of the genotypic variation in $P$. capitalensis as opposed to $P$. citricarpa, and ultimately, $P$. capitalensis may need to be split into different taxa, considering that $P$. capitalensis strains have been allocated to different teleomorphs (Baayen et al., 2002; Glienke et al., 2011; Okane et al., 2001).

\section{ACKNOWLEDGEMENTS}

We are grateful to Dr. Walter Bowen, director of the International Office of the Institute of Food and Agricultural Sciences (IFAS) of the University of Florida for providing an internship fellowship to the first author from UF Project\#00091381 funded by the Ecuador Scientific Exchange Program sponsored by the USDA. This project was also partially funded by USDA-APHIS project number 98083 . We thank Dr. Tim Schubert for providing a culture of P. citricarpa (DPI- 35197) and Dr. Matthew Smith for initial help with primer selection. We also thank Dr. Pedro Crous for the useful discussion about Phyllosticta taxonomy.

\section{REFERENCES}

Arnold EA, Mejía LC, Kyllo D, Rojas EI, Maynard Z, Robbins N, Herre EA (2003) Fungal endophytes limit pathogen damage in a tropical tree. Proceedings of the National Academy of Sciences of the United States of America 100:15649-15654.

Baayen RP, Bonants PJM, Verkley G, Carroll GC, van der Aa HA, de Weerdt M, van Brouwershaven IR, Schulte GC, Maccheroni W, de Blanco CG, Azevedo Jl (2002) Nonpathogenic isolates of the citrus black spot fungus, Guignardia citricarpa, identified as a cosmopolitan endophyte of woody plants, G. mangiferae (Phyllosticta capitalensis). Phytopathology 92:464-477.

Baldassari RB, Wickert E, de Goes A (2008) Pathogenicity, colony morphology and diversity of isolates of Guignardia citricarpa and G. mangiferae isolated from Citrus spp. European Journal of Plant Pathology 120:103-110.

Bezerra JPD, Santos MGS, Svedese VM, Lima DMM, Fernandes MJS, Paiva LM, Souza-Motta CM (2012) Richness of endophytic fungi isolated from Opuntia ficus-indica Mill. (Cactaceae) and preliminary screening for enzyme production. World Journal Microbiology Biotechnology 28:1989-1995.

Brentu FC,Oduro KA, Offei SK, Odamtten Gt, Vicent A, Peres NA, Timmer LW (2012) Crop loss, etiology, and epidemiology of citrus black spot in Ghana. European Journal of Plant Pathology 133:657-670.

Carbone I, Kohn LM (1999) A method for designing primer sets for speciation studies in filamentous ascomycetes. Mycologia 
Genetic variation among Phyllosticta strains isolated from citrus in Florida...

\section{1:553-556.}

Chiyaka C, Singer BH, Halbert SE, Morris JG, van Bruggen AHC (2012) Modeling huanglongbing transmission within a citrus tree. Proceedings of the National Academy of Sciences 109:1221312218.

Dewdney MM, Schubert TS, Estes MR, Peres NA (2012) Florida Citrus Pest Management Guide: Citrus Black Spot, University of Florida IFAS Extension PP279. 6 pp.

Er HL, Hendricks K, Goss EM, Smith M, Schubert TS, Roberts PD, van Bruggen AHC (2013a) Isolation and biological characterization of Guignardia species from citrus in Florida. Journal of Plant Pathology (in press).

Er HL, Roberts PD, Marois JJ van Bruggen AHC (2013b) Potential distribution of citrus black spot in the USA based on climatic conditions. European Journal of Plant Pathology 137:635-647.

Everett KR, Rees-George J (2006) Reclassification of an isolate of Guignardia citricarpa from New Zealand as Guignardia mangiferae by sequence analysis. Plant Pathology 55:194-199.

Excoffier L, Schneider S (2005) Arlequinver 3.0: an integrated software package for population genetics data analysis. Evolutionary Bioinformatics Online 1:47-50.

Glienke C, Pereira OL, Stringari D, Fabris J, Kava-Cordeiro V, Galli-Terasawa L, Cunnington J, Shivas RG, Groenewald JZ, Crous PW (2011) Endophytic and pathogenic Phyllosticta species, with reference to those associated with Citrus Black Spot. Persoonia 26:47-56.

Glienke-Blanco C, Aguilar-Vildoso CI, Vieira MLC, Barroso PAV, Azevedo JL (2002) Genetic variability in the endophytic fungus Guignardia citricarpa isolated from citrus plants. Genetics and Molecular Biology 25:251-255.

Guerber JC, Liu B, Correll JC, Johnston PR. 2003. Characterization of diversity in Colletotrichum acutatum sensu lato by sequence analysis of two gene introns, mtDNA and intron RFLPs, and mating compatibility. Mycologia 95:872-895.

Guindon S, Gascuel O (2003) A simple, fast, and accurate algorithm to estimate large phylogenies by maximum likelihood. Systematic Biology 52:696-704.

Johnston PR (1998) Leaf endophytes of manuka (Leptospermum scoparium). Mycological Research102:1009-1016.

Kelemu S, White JF, Muñoz F, Takayama Y (2001) An endophyte of the tropical forage grass Brachiaria brizantha: isolating, identifying, and characterizing the fungus, and determining its antimycotic properties. Canadian Journal of Microbiology 47:5562.

Kotzé JM (1981) Epidemiology and control of citrus black spot in South Africa. Plant Disease Reporter 65:945-950.

Mejía LC, Rojas EI, Maynard Z, van Bael S, Arnold AE, Hebbar P, Samuels GJ, Robbins N, Herre EA (2008) Endophytic fungi as biocontrol agents of Theobroma cacao pathogens. Biological Control 46:4-14.

Myllys L, Stenroos S, Thell A (2002) New genes for phylogenetic studies of lichenized fungi: glyceraldehyde-3-phosphate dehydrogenase and beta tubulin genes. Lichenologist 34:237-246.

Okane I, Nakagiri A, Ito T (2001) Identity of Guignardia sp. inhabiting ericaceous plants. Canadian Journal of Botany 79:101109.
OkaneI, Lumyong S, Nakagiri A, Ito T (2003) Extensive host range of an endophytic fungus, Guignardia endophyllicola (anamorph: Phyllosticta capitalensis). Mycoscience 44:353-363.

Paul I., van Jaarsveld A.S., Korsten L., Hattingh V (2005) The potential global geographical distribution of Citrus Black Spot caused by Guignardia citricarpa (Kiely): likelihood of disease establishment in the European Union. Crop Protection 24:297308.

Rakotoniriana EF, Munaut F, Decock C, Randriamampionona D, Andriambololoniaina M, Rakotomalala T, Rakotonirina EJ, Rabemanantsoa C, Cheuk K, Ratsimamanga SU, Mahillon J, ElJaziri M, Quetin-Leclercq J, Corbisier AM (2008) Endophytic fungi from leaves of Centella asiatica: occurrence and potential interactions within leaves. Antonie van Leeuwenhoek 93:27-36.

Rodrigues KF, Hesse, M, Werner C (2000) Antimicrobial activities of secondary metabolites produced by endophytic fungi from Spondias mombin. Journal of Basic Microbiology 40:261-267.

Rodrigues KF, Sieber TN, Grünig CR, Holdenrieder O (2004) Characterization of Guignardia mangiferae isolated from tropical plants based on morphology, ISSR-PCR amplifications and ITS15.8S-ITS2 sequences. Mycological Research 108:45-52.

Rodrigues KF, Samuels GJ (1999) Fungal endophytes of Spondias mombin leaves in Brazil. Journal of Basic Microbiology 39:131135.

Romão AS, Spósito MB, Andreote FD, Azevedo JL, Araújo WL (2011) Enzymatic differences between the endophyte Guignardia mangiferae (Botryosphaeriaceae) and the citrus pathogen $G$. citricarpa. Genetics and Molecular Research 10:243-252.

Rozas J, Sanchez-DelBarrio JC, Messeguer X, and Rozas R (2003) DnaSP, DNA polymorphism analyses by the coalescent and other methods. Bioinformatics 19:2496-2497.

Schubert TS, Dewdney MM, Peres NA, Palm MA, Jeyaprakash A, Sutton B, Mondal SN, Wang N-Y, Rascoe J, Picton DD (2012) First report of Guignardia citricarpa associated with citrus black spot on sweet orange [Citrus sinensis (L.) Osbeck] in North America. Plant Disease 96:1225.

Shen W, Halbert SE, Dickstein E, Manjunath KL, Shimwela MM, van Bruggen AHC (2013) Occurrence and in-grove distribution of citrus huanglongbing in north central Florida. Journal of Plant Pathology 95:361-371.

Stringari D, Glienke C, de Christo D, Maccheroni W Jr, de Azevedo JL (2009) High molecular diversity of the fungus Guignardia citricarpa and Guignardia mangiferae in new primers for the diagnosis of the citrus black spot. Brazilian Archives of Biology and Technology 52:1063-1073.

Su YY, Cail L (2012) Polyphasic characterisation of three new Phyllosticta spp. Persoonia 28:76-84.

Tamura K, Peterson D, Peterson N, Stecher G, Nei M, Kumar S (2011) MEGA5: Molecular evolutionary genetics analysis using maximum likelihood, evolutionary distance, and maximum parsimony methods. Molecular Biology and Evolution 28:27312739.

Wang X, Chen G, Huang F, Zhang J, Hyde KD, Li H (2012) Phyllosticta species associated with citrus diseases in China. Fungal Diversity 52:209-224.

White TJ, Bruns T, Lee S, Taylor J (1990) Amplification and direct sequencing of fungal ribosomal RNA genes for phylogenetics. 
In: Innis MA, Gelfand DH, Sninsky JJ, White TJ (Eds.), PCR Protocols: A guide to methods and applications. San Diego. USA. Academic Press. pp. 315-322.

Wickert E, de Goes A, de Souza A, Gertrudes de Macedo Lemos E (2012a) Genetic diversity and population differentiation of the causal agent of citrus black spot in Brazil. The Scientific World Journal 2012, Article ID 368286. 14pp.

Wickert E, Gertrudes de Macedo Lemos E, Takeshi Kishi L, de Souza A, de Goes A (2012b) Genetic diversity and population differentiation of Guignardia mangiferae from "Tahiti" acid lime. The Scientific World Journal 2012, Article ID 125654, 11 pages
Wikee S, Udayanga D, Crous PW, Chukeatirote E, McKenzie EHC, Bahkali AH, Dai DQ, Hyde KD (2011) Phyllosticta: an overview of current status of species recognition. Fungal Diversity 51:43-61.

Wulandari NF, To-anun C, Hyde KD, Duong LM, de Gruyter J, Meffert JP, Groenewald JZ, Crous PW (2009) Phyllosticta citriasiana sp. nov., the cause of citrus tan spot of Citrus maxima in Asia. Fungal Diversity 34:23-39.

Yuan Z, Chen Y, Yang Y (2009) Diverse non-mycorrhizal fungal endophytes inhabiting an epiphytic, medicinal orchid (Dendrobium nobile): estimation and characterization. World Journal of Microbiology and Biotechnology 25:295-303.

TPP-2013-0136

Submitted: 9 August 2013

Revisions requested: 25 September 2013

Accepted: 26 October 2013

Section Editor: Thomas Harrington 